\title{
Larval production, dispersal, and growth in a fjord: a case study on larvae of the sand dollar Dendraster excentricus
}

\author{
Richard B. Emlet* \\ Dept. of Zoology and Friday Harbor Laboratories, University of Washington, Seattle, Washington 98195, USA
}

\begin{abstract}
In a small shallow fjord with predominantly wind-driven circulation, larvae of the sand dollar Dendraster excentricus (Eschscholtz) do not persist for longer than 2 wk after a local population in the fjord spawns. Changes in distribution and abundance of larval cohorts indicate that larvae are advected out of the fjord and thus contribute to a regional larval pool. A series of plankton samples at the start of 2 reproductive seasons showed that cohorts of larvae are produced during spring tides that expose the intertidal adult population to air. Growth rates of 1 to $3 \mathrm{wk}$ old larvae of $D$. excentricus and Strongylocentrotus franciscanus in the fjord are comparable to those reared in the laboratory. Later in the season, advanced-stage larvae of $D$. excentricus are found in surface waters in the fjord; this may enhance their chances of locating suitable habitat for settlement. Many of these advanced-stage larvae have shortened larval arms that may indicate delayed metamorphosis.
\end{abstract}

\section{INTRODUCTION}

A substantial portion of the temperate coastal ocean consists of fjords, bodies of marine water that are partly enclosed by land and whose water exchange with the open sea is restricted by sills (Pearson 1980). The oceanographic processes controlling flushing and mixing in these water masses are relatively well understood (e.g. Freeland et al. 1980) and must ultimately influence the retention or dispersal of larvae of benthic marine invertebrates to fjord habitats suitable for adult life. Pearson (1970), Gage (1972), and Rasmussen (1973) have all remarked that the abundance of marine organisms in fjords and the often broad habitat distributions of benthic species relative to non-fjord areas may be due to the retention of larvae and their subsequent abundant settlement in fjords.

Larval supply, settlement and post-settlement survivorship all may influence structure of benthic communities (e.g. Keough \& Downes 1982, Underwood \& Denley 1984, Gaines \& Roughgarden 1985). Larval supply is notoriously hard to measure. Where larvae

- Present address: Dept. of Invertebrate Zoology, Natural History Museum, Smithsonian Institution, Washington, D.C. 20560, USA are transported, how fast they grow, how readily they are eaten while in the plankton and what mechanisms bring larvae into contact with suitable benthic habitats are basic questions in population ecology and life history biology, yet they are rarely studied in the field. Because fjord populations provide known sources of larvae and because oceanographic processes in fjords are relatively simple, sampling a larval population is facilitated.

In this paper I present results of a field study of larvae of the sand dollar Dendraster excentricus (Eschscholtz) produced by a population in a fjord (Fig. 1). The information answers the first 5 of the following 6 questions. Data on larval size and form also bear on the last question. (1) Are planktonic larvae retained in the immediate area after release from a population of benthic adults? (2) How variable between seasons and lunar-tidal cycles is onset of larval production? (3) How do development rates inferred from plankton samples compare with those in laboratory rearing? (4) Are early-stage larvae concentrated at certain depths and how could depth distribution affect retention? (5) Are late-stage larvae concentrated at certain depths and could this affect return to suitable adult habitat? (6) Is there evidence for delay of metamorphosis by larvae in the plankton? 


\section{STUDY ORGANISM AND STUDY AREA}

Dendraster excentricus occurs in dense aggregations (200 to $1000 \mathrm{~m}^{-2}$ ) in shallow subtidal sandy habitats on the outer coast and some protected intertidal habitats from Baja California to Southern Alaska (Merrill \& Hobson 1970). In Puget Sound, Washington, USA, populations (called beds) occur intertidally in sandy embayments; some of these populations have been in existence for a minimum of 53 to $78 \mathrm{yr}$ (Bovard \& Osterud 1918, Birkeland \& Chia 1971). Throughout its range, $D$. excentricus releases gametes during the summer and fall into the water where fertilization occurs (Niesen 1977, Cameron \& Rumrill 1982, author's obs.). Feeding larvae take $3 \mathrm{wk}$ to 2 mo to develop to the point where they are competent to metamorphose (Strathmann 1978, Cameron \& Rumrill 1982, Highsmith 1982, author's obs.). Larvae are induced to metamorphose in the presence of adults by a low molecular weight compound associated with the sand in which adults live (Highsmith 1982, Burke 1984).

East Sound, Washington, is a shallow fjord of $30 \mathrm{~m}$ mean depth, approximately $10 \mathrm{~km}$ length, and $1.5 \mathrm{~km}$ average width. At the southern entrance to the sound a sill, 10 to $15 \mathrm{~m}$ shallower than surrounding bottom, extends approximately half-way across the mouth. East Sound has minimal freshwater input and lacks a lower salinity surface layer common to many fjords. A brief study of circulation (Rattray 1967) and 4 separate summer profiling studies conducted by biological oceanography courses at nearby Friday Harbor
Laboratories (FHL) in the 1970's (summarized by King 1976) showed that circulation in East Sound is primarily wind-driven. Though a 2 to $3 \mathrm{~m}$ tide (mixed, semidiurnal cycle) in the area flushes water back and forth over the sill, tidal currents in East Sound are negligible. Wind-driven circulation moves surface waters in or out of the sound depending on wind direction and sets up a deeper current which moves in the direction opposite to the wind-driven surface waters. In the summer, water is weakly stratified with a pycnocline approximately $10 \mathrm{~m}$ deep. The highest land in the San Juan Archipelago, Mount Constitution (elevation $700 \mathrm{~m}$ ) forms the eastern shore of East Sound and affects wind patterns on the sound. Due to the mountain, wind on the sound is restricted to north or south direction, and can be different in magnitude from the wind over surrounding waters.

There are 2 populations of Dendraster excentricus in East Sound (Fig. 1). The larger of the two and the focus of this study is located at the extreme North end of the sound at Crescent Beach. This population extends along $500 \mathrm{~m}$ of beach and is located at $0.0 \mathrm{~m}$ (MLLW) $\pm 0.2 \mathrm{~m}$. Estimated population size is $5 \times 10^{6}$ individuals $\pm 20 \%$ (author's unpubl. obs.). The second population is located more than $10 \mathrm{~km}$ away at Olga, on the eastern shore just outside of the entrance to East Sound. This population is restricted to approximately $40 \mathrm{~m}$ of shoreline also at about MLLW and is estimated to contain 2.5 to $5 \times 10^{5}$ individuals (author's unpubl. obs.). A third, extremely small population (ca 5000 individuals) exists $6.5 \mathrm{~km}$ away from East Sound in

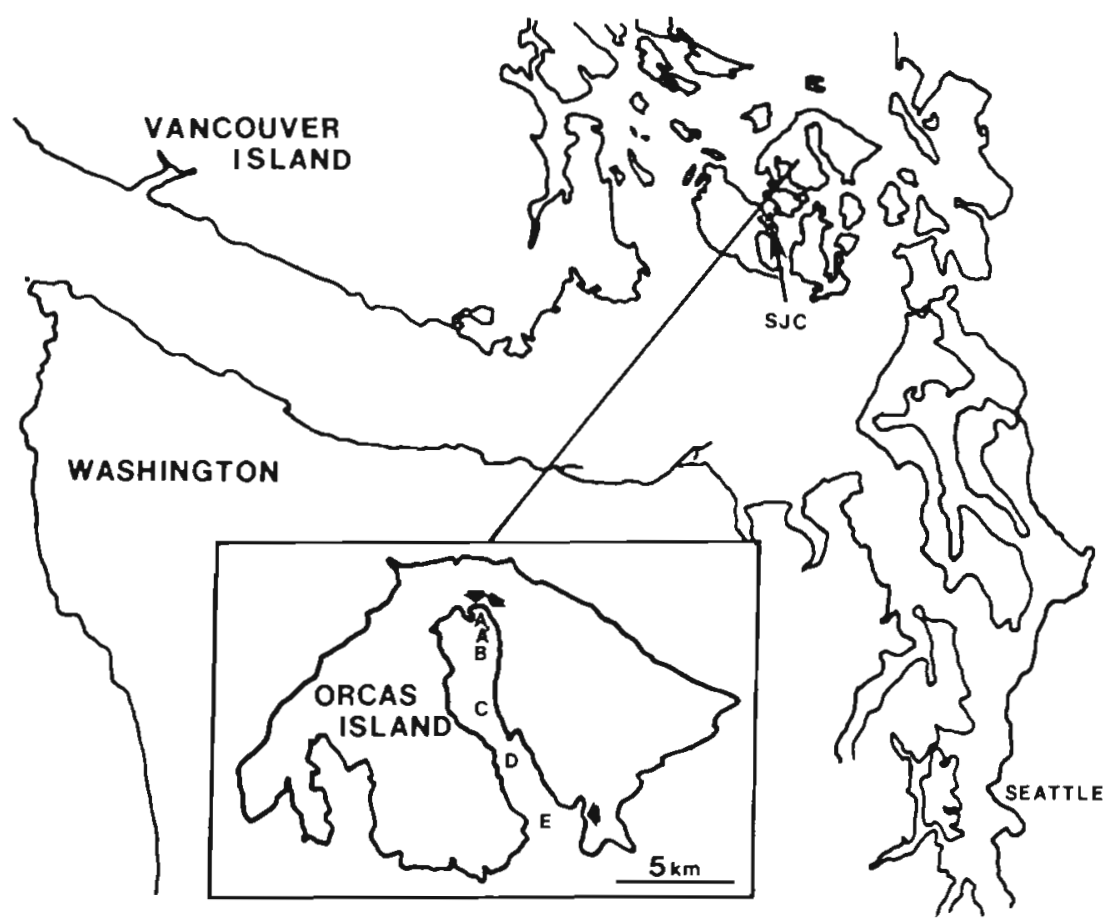

Fig. 1. Composite map of study area, Regional map of Western Washington, San Juan Archipelago, and southem Vancouver Island. SJC indicates site in San Juan Channel where reference plankton samples were collected. Inset map is Orcas Island. Collection sites in East Sound are indicated $\left(A, A^{\prime}, B, C, D, E\right)$ and the locations of the adult sand dollar bed are shown by arrows. Double arrows: the large Crescent Beach population; single arrow: the Olga population 
Shoal Bay on Lopez Island. Other known local populations are more than $20 \mathrm{~km}$ from the entrance to East Sound.

\section{METHODS}

Plankton was sampled regularly in East Sound and at 1 site in San Juan Channel during the beginning of the sand dollar reproductive season (May and June) and occasionally later in the season during 1982 and 1983. All samples were fixed in $3 \%$ buffered formalin immediately upon collection.

In 1982, samples were taken with a $125 \mu \mathrm{m}$ mesh net with a $1 / 4 \mathrm{~m}$ diameter opening. Vertical tows were taken at established sites along the axis of East Sound (Fig. 1). One to 3 vertical tows were collected at each site. Forty-six site-dates are reported; 10 of these have 3 replicate tows and 9 others have 2 replicate tows incorporated into the mean values reported (Table $1 \mathrm{~A}$, B). Replicates were restricted primarily to Sites A, B, and $\mathrm{C}$ and never occurred at Site D or at the SJC site. All net tows were made from a depth of $25 \mathrm{~m}$ to the surface except Site A where tows were taken from the bottom (10 to $12 \mathrm{~m})$ to the surface. Net tows were taken at approximately $1 \mathrm{wk}$ intervals from mid-May to midJune. When larvae were found in abundance, followup samples were collected 2 to $3 \mathrm{~d}$ later. No attempt was made to quantify volume sampled or to correct for the differences in volume sampled between Site $A$ and the other sites. Dense phytoplankton blooms began in East Sound in late May 1982 and reduced the volume sampled by the net. On one occasion in October 1982 , horizontal tows were taken at 2 depths at Site $C$ to collect surface waters $(0$ to $1 \mathrm{~m})$ and deeper waters $(\sim 10 \mathrm{~m})$.

In 1983, plankton samples were collected primarily with a plankton pump. Samples were pumped from the surface ( $1 \mathrm{~m}$ depth), from 10 to $15 \mathrm{~m}$ depth and on occasion from an intermediate depth $(6 \mathrm{~m})$. During May and June pump samples were taken approximately semiweekly at Sites A, A', and B, and also directly over the adult sand dollar population. A sample of 0.8 to $0.97 \mathrm{~m}^{3}$ of water was pumped and filtered through a $125 \mu \mathrm{m}$ mesh net during $3 \mathrm{~min}$. Occasionally net tows were also taken. In August of 1983, a series of pump samples was collected together with temperature and salinity data along a transect that corresponded with the sites established the previous year.

During both years, a sample was also collected in San Juan Channel (SJC in Fig. 1) every day that East Sound was sampled. San Juan Channel, one of the main tracts of tidal movement of water through the San Juan Archipelago, is well mixed. The sample from SJC is a reference for larvae present in waters that did not originate in East Sound and so indicates supply of larvae from the surrounding region.

In all 1982 samples, number and stage of larvae of Dendraster excentricus and of the red urchin, Strongylocentrotus franciscanus (A. Agassiz) were determined for the entire sample. Larvae of $S$. franciscanus were counted because they were abundant and indicate water from outside East Sound (see below). The 1983 samples were split with a Folsom plankton splitter and half of each was counted. Numbers of larvae (rounded to the nearest integer) are reported as no. per vertical tow in 1982 and no. $\mathrm{m}^{-3}$ in 1983.

The skeleton of echinopluteus larvae is composed of calcareous rods and can be used to identify species (Mortensen 1921). The larvae of Dendraster excentricus were identified by their transparent larval body and fenestrated arm rods (Strathmann 1979). The larval skeleton of Strongylocentrotus franciscanus possesses a recurrent body rod that makes this species easily distinguishable from larvae of other Strongylocentrotus species (Strathmann 1979). Other Strongylocentrotus larvae, such as those of $S$. droebachiensis and $S$. purpuratus, were seen only rarely during the study.

As echinopluteus larvae develop, they add new pairs of arms and older arms grow longer. The postoral pair of arms develop first, followed by pairs of anterolaterals, posterodorsals, and lastly preorals (Mortensen 1921, McEdward 1984). Larvae were staged by the number of pairs of arms or arm rods, by length of the postoral and posterodorsal rods, and at late stages, by the degree of development of juvenile rudiment. Rod length was measured from the distal tip to the base at the origin of the transverse process. Data for postoral rod lengths are from haphazardly chosen larvae from a given sample.

\section{RESULTS}

\section{Origin and dispersal of cohorts}

Distinct cohorts of larvae appeared in East Sound during the beginning of both the 1982 and 1983 reproductive seasons (Tables 1 \& 2). On 2 occasions each year during the May-June period, larvae of Dendraster excentricus were first present in highest abundance at Site A or over the sand dollar population (Tables $1 \mathrm{~A} \&$ 2 ). On each date $>99 \%$ of these larvae were at the 4 armed stage indicating they were less than $1 \mathrm{wk}$ old and that they were most likely produced by that local population of sand dollars.

In 1982, these cohorts of larvae produced by the local population did not persist in East Sound. On 16 May, $2 \mathrm{~d}$ after the first cohort was found, the abundance of larvae of Dendraster excentricus had dropped by an 
order of magnitude (Table $1 \mathrm{~A}$ ). A week later no sand dollar larvae were found within $10 \mathrm{~km}$ of the adult population at Crescent Beach. The second cohort of larvae also rapidly decreased within $3 \mathrm{~d}$ after it was first noted (Table $1 \mathrm{~A}$ ).

In 1983, the first cohort of larvae occurred later in
May and was apparently smaller in magnitude than the previous year (Table 2). Semiweekly plankton sampling was started in late April 1983, but the first cohort of sand dollar larvae was not seen until 26 May. In mid-June, a second and much more abundant cohort was produced (Table 2).

Table 1. (A) Dendraster excentricus. Abundance and distribution of larvae in East Sound and SJC, 1982. Numbers at each site are numbers of larvae tow ${ }^{-1}$. For replicate tows, the mean number to $w^{-1}$ rounded to the nearest integer and the range (in parentheses) are given. Dashes: no data. Site locations are shown in Fig. 1

\begin{tabular}{|c|c|c|c|c|c|c|c|c|}
\hline \multirow[t]{2}{*}{ Site } & \multicolumn{8}{|c|}{ Date } \\
\hline & 14 May & $16 \mathrm{May}$ & 23 May & 30 May & 7 Jun & 16 Jun & 19 Jun & 4 Oct \\
\hline $\mathrm{A}$ & $57(40-71)$ & 4 & $0(0)$ & $1(0-1)$ & $4(1-7)$ & $84(43-125)$ & $10(7-13)$ & $3(1-5)$ \\
\hline B & $10(3-19)$ & 0 & $0(0)$ & $2(2)$ & $3(2-3)$ & $16(14-17)$ & $6(3-8)$ & $2(1-4)$ \\
\hline C & 13 & 3 & $0(0)$ & $1(0-2)$ & 3 & 23 & 8 & $3(2-3)$ \\
\hline $\mathrm{D}$ & - & 5 & 0 & 1 & 1 & 15 & 6 & 1 \\
\hline $\mathrm{E}$ & - & 5 & $5(2-7)$ & 1 (1) & 2 & 1 & 4 & 7 \\
\hline $\mathrm{SJC}$ & 0 & 2 & 2 & 1 & 1 & 3 & 7 & 0 \\
\hline
\end{tabular}

(B) Strongylocentrotus franciscanus. Abundance of larvae, 1982. The numbers at each site are mean number of larvae tow ${ }^{-1}$ Data reported as in A

\begin{tabular}{cccccc}
\hline Site & 23 May & 30 May & 7 Jun & 16 Jun & 19 Jun \\
\hline A & $0(0)$ & $9(6-11)$ & $0(0)$ & $1(1)$ & $1(0-2)$ \\
B & $1(0-2)$ & $11(5-16)$ & $1(0-1)$ & $1(1)$ & $3(2-3)$ \\
C & $10(6-18)$ & $12(7-19)$ & 0 & 0 & 3 \\
D & 45 & 14 & 0 & 1 & 4 \\
E & $318(283-353)$ & $9(7-11)$ & 2 & 1 & 17 \\
SJC & 169 & 5 & 5 & 15 & 17 \\
\hline
\end{tabular}

Table 2. Dendraster excentricus. 1983. Abundance and distribution of larvae in East Sound and SJC are shown as numbers of larvae $\mathrm{m}^{-3}$ at each depth at each site. (Values are rounded to the nearest integer). Dashes: no data. Samples on $11 \mathrm{May}, \mathrm{SJC}$ samples (except those on 20 and 22 Aug), and the site over the adult bed and Site B on 26 May were net samples. Net samples cannot be compared directly with pump samples because of different sample volumes, so only presence/absence data (+/0) is reported for net samples ( + : numerous larvae). Samples on 20 and 22 Aug contained both precompetent (first number) and competent (second number) larvae

\begin{tabular}{|c|c|c|c|c|c|c|c|c|c|c|}
\hline \multirow[t]{2}{*}{ Site } & \multicolumn{10}{|c|}{ Date } \\
\hline & 11 May & $18 \mathrm{May}$ & 22 May & 26 May & $29 \mathrm{May}$ & 4 Jun & 12 Jun & $16 \mathrm{Jul}$ & $20 \mathrm{Aug}$ & 22 Aug \\
\hline Over adult bed & 0 & 0 & 0 & ++ & 0 & 0 & 280 & 0 & - & 52,11 \\
\hline A $\begin{array}{r}1 \mathrm{~m} \\
10 \mathrm{~m}\end{array}$ & 0 & $\begin{array}{l}0 \\
0\end{array}$ & $\begin{array}{l}0 \\
0\end{array}$ & $\begin{array}{l}0 \\
4\end{array}$ & $\begin{array}{l}0 \\
0\end{array}$ & - & $\begin{array}{r}657 \\
4\end{array}$ & - & $\begin{array}{l}- \\
-\end{array}$ & $\begin{array}{l}0,2 \\
0,0\end{array}$ \\
\hline $\begin{array}{r}\mathrm{A}^{\prime} \mathrm{m} \\
6 \mathrm{~m} \\
12 \mathrm{~m}\end{array}$ & 0 & $\begin{array}{l}0 \\
- \\
2\end{array}$ & $\begin{array}{l}0 \\
0 \\
2\end{array}$ & $\begin{array}{l}0 \\
3 \\
3\end{array}$ & $\begin{array}{l}0 \\
0 \\
0\end{array}$ & $\begin{array}{l}0 \\
2 \\
0\end{array}$ & $\begin{array}{r}563 \\
90 \\
2\end{array}$ & $\begin{array}{l}0 \\
0 \\
0\end{array}$ & $\begin{array}{l}45,13 \\
- \\
-\end{array}$ & $\begin{array}{l}- \\
- \\
-\end{array}$ \\
\hline $\begin{array}{r}\text { B } 1 \mathrm{~m} \\
15 \mathrm{~m}\end{array}$ & 0 & 0 & $\begin{array}{l}0 \\
0\end{array}$ & 0 & - & - & - & - & - & $\begin{array}{l}0,40 \\
0,0\end{array}$ \\
\hline C $\begin{array}{r}1 \mathrm{~m} \\
15 \mathrm{~m}\end{array}$ & 0 & - & - & - & - & - & - & - & $\begin{array}{c}38,29 \\
-\end{array}$ & $\begin{array}{l}0,31 \\
5,0\end{array}$ \\
\hline E $\begin{array}{r}1 \mathrm{~m} \\
15 \mathrm{~m}\end{array}$ & 0 & - & - & - & - & - & - & - & $\begin{array}{l}3,0 \\
-\end{array}$ & $\begin{array}{l}0,16 \\
3,0\end{array}$ \\
\hline $\mathrm{SJC}$ & 0 & + & + & + & - & + & 0 & - & 9,5 & 13,2 \\
\hline
\end{tabular}


Stage analysis of larvae of Dendraster excentricus caught in the samples in 1982 shows growth of the larval arms between 14 and 16 May and between 16 and 23 May. The mean lengths of postoral arm rods of larvae in East Sound are different for each date $(P<0.05$ for each pair of means using the TukeyKramer method of multiple comparisons, from Sokal \& Rohif 1981). The arm growth is consistent with the hypothesis that these larvae represent a cohort (Fig. 2).

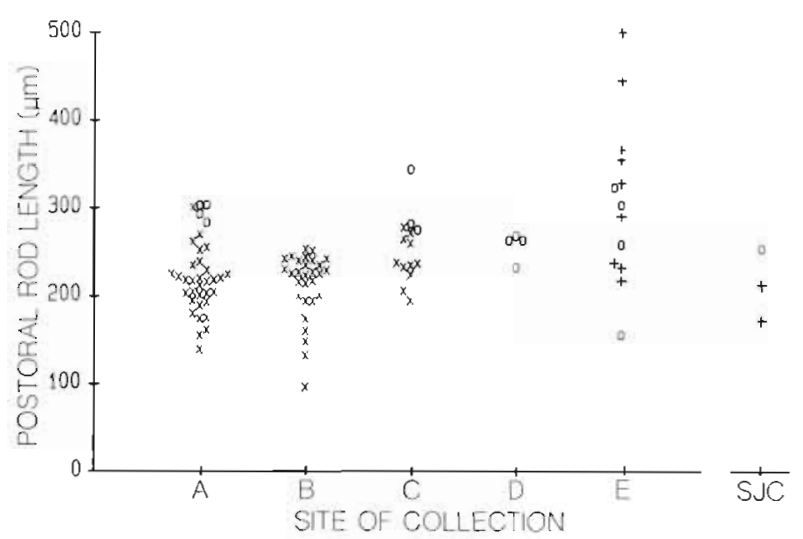

Fig. 2. Dendraster excentricus. Distribution and stage of first cohort of larvae in East Sound, May 1982. Abscissa: position in East Sound; left end closest to adult sand dollar bed Ordinate: length of postoral rod, a measure of larval stage. (x): 14 May; (o): 16 May; (+): 23 May

The few larvae of $D$. excentricus that were found in SJC during this period were all at earlier or later stages of development. It is therefore unlikely that the larvae sampled in East Sound were immigrants from outside the sound, though it is possible that the 16 and 23 May samples included some larvae produced by the sand dollar bed at Olga in the mouth of East Sound.

The rapid diminution of the larval population of Dendraster excentricus in the sound in May of 1982 is partly due to export and dilution of East Sound water.

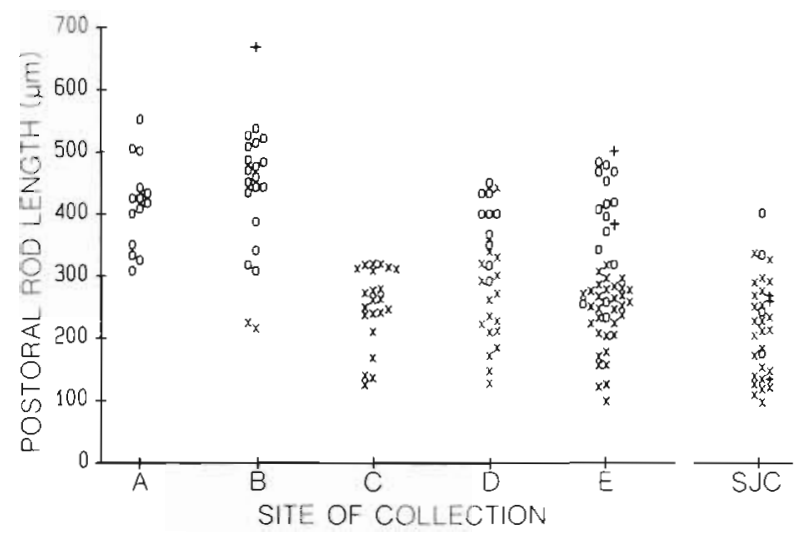

Fig. 3. Strongylocentrotus franciscanus. Distribution and stage of larvae in East Sound, May-Jun 1982. Format as in Fig. 2. (x): 23 May; (o): 30 May; (+): 7 Jun
Evidence for transport comes from the data on occurrence of larvae of Strongylocentrotus franciscanus. Samples from 23 and 30 May show that a large pulse of these larvae moved into the sound and diminished by 7 June (Table 1B, Fig. 3). Most of the larvae of $S$. franciscanus found in East Sound on 23 May were at the early 4 -armed stage. In the 2 subsequent samples, larvae had longer arms. Mean lengths of postoral arm rods for larvae of $S$. franciscanus in East Sound were different for each these 3 dates. $(P<0.05$ for each pair of means using the Tukey-Kramer method of multiple comparisons, from Sokal \& Rohlf 1981). During the same period, larvae of $S$. franciscanus from SJC were generally at earlier stages than those in East Sound, indicating that the regional adult populations were continually spawning and that the older larvae found in East Sound on 30 May and 7 June probably had first entered the sound on 23 May (Fig. 3).

Larvae of Strongylocentrotus franciscanus are a good marker of water from outside East Sound because adults of this species are not known to occur there. This species was not found on the appropriate substrate in approximately a dozen dives at various sites around East Sound (author's own obs., S. Norton pers. comm.) and not even 1 individual has been collected in East Sound by extensive bottom trawling by a vessel from Friday Harbor Labs over the past 3 yr.

An increased abundance of larvae of Strongylocentrotus franciscanus was noted in SJC on 16 June (Table $1 \mathrm{~B}$ ). These larvae were 4 -armed and probably less than 1 wk old. On 19 June larvae in SJC and East Sound were of a similar stage, so larvae continued to enter East Sound between 16 and 19 June.

Larvae of Dendraster excentricus were found in East Sound from May through October. The October (1982) sample from East Sound contained all stages of larvae. Advanced stage larvae, nearing metamorphosis, were not seen in East Sound during May and June of either year.

\section{Timing of larval production}

Cohort age and date of gamete release for Dendraster excentricus in East Sound were estimated by comparing the stage of field-collected larvae with larvae reared in the laboratory at 10 to $12^{\circ} \mathrm{C}$ (Table 3). Only the earlier stages can be aged in this manner because later development depends on food availability (e.g. Paulay et al. 1985). The first release of larvae in 1983 was the youngest cohort sampled ( 2 to $3 \mathrm{~d}$ ), though the range of ages for the other cohorts is 3 to $5 \mathrm{~d}$. All estimated dates of release correspond with spring tides that exposed the sand dollar bed at low tide in midmorning or afternoon. The smallest pulse on 26 May 1983 departs farthest from the pattern because spawn- 
Table 3. Dendraster excentricus. Timing of release of larvae in East Sound. Date the pulse of larvae was first noted and length of postoral rods from lab reared larvae were used to estimate age of larvae and day of release from the Crescent Beach population

\begin{tabular}{|c|c|c|c|c|}
\hline $\begin{array}{l}\text { Pulse } \\
\text { date }\end{array}$ & $\begin{array}{c}\text { Mean } \\
\text { length of } \\
\text { postoral rod } \\
\text { (um) }\end{array}$ & $\begin{array}{l}\text { Sample } \\
\text { size }\end{array}$ & $\begin{array}{c}\text { Estimated } \\
\text { larval } \\
\text { age } \\
\text { (d) }\end{array}$ & $\begin{array}{c}\text { Estimated } \\
\text { date of } \\
\text { spawning }\end{array}$ \\
\hline 14 May 1982 & 213 & 32 & 4 & $10 \mathrm{May}$ \\
\hline 16 Jun 1982 & 237 & 45 & $4-5$ & 11-12 Jun \\
\hline 26 May 1983 & 97 & 8 & $2-3$ & 23-24 May \\
\hline 12 Jun 1983 & 181 & 30 & $3-4$ & $9-10 \mathrm{Jun}$ \\
\hline
\end{tabular}

ing occurred at the beginning of a spring tide series when the adult population was exposed for only a short time $(<1 \mathrm{~h})$.

\section{Larval growth rates in the field}

The growth rates of larvae of Dendraster excentricus and Strongylocentrotus franciscanus in the field were comparable to intermediate rates reported for laboratory cultures. The first larval cohort of $D$. excentricus was estimated to be $4 \mathrm{~d}$ old when found on $14 \mathrm{May}$, and if the few 6-armed stages found at Site $E$ on 23 May were from this first cohort, they would be $13 \mathrm{~d}$ old. The 6-armed larvae from 23 May had mean postoral and posterodorsal rod lengths of $400 \mu \mathrm{m}$ and $210 \mu \mathrm{m}$, respectively $(n=5)$. This growth rate is similar to that reported for temperatures of 10 to $14^{\circ} \mathrm{C}$ by $\mathrm{M}$. Strathmann (1974). McEdward's (1984) data on arm growth in 2 laboratory cultures of $D$. excentricus show both faster and slower growth than estimated here, but direct comparison is limited because different criteria were used to measure arm length. Developmental times from fertilization to metamorphosis for $D$. excentricus range from 17 to $162 \mathrm{~d}$ and are strongly affected by temperature and culture conditions including food quality and quantity. The most commonly reported developmental times to metamorphosis in the laboratory are 28 to $42 \mathrm{~d}\left(10\right.$ to $\left.14^{\circ} \mathrm{C}\right)$. Cameron \& Rumrill (1982) reported that the $9 \mathrm{~d}$ interval they observed between the 4 - and 6-armed stage of larvae from Monterey Bay, California, was comparable to laboratory growth rates.

Larvae of Strongylocentrotus franciscanus found in East Sound from 23 May to 7 June 1982 showed a developmental rate equivalent to that reported for similar stages in the laboratory (M. Strathmann 1974). Based on laboratory data of larval development at $10^{\circ} \mathrm{C}$, the 4 -armed larvae found on 23 May were approximately 1 wk old (author's obs., M. Strathmann
1974). By 30 May, $30 \%$ of the larvae were growing posterodorsal arms, and by 7 June the few larvae that remained in East Sound had well-developed posterodorsal arms.

\section{Patterns of vertical distribution of larvae}

Pump samples from 1983 showed no consistent vertical stratification of larvae of early stages. On the 4 dates prior to 12 June and on 22 August, the few 4 - and 6 -armed sand dollar larvae found in East Sound were at intermediate depth $(6 \mathrm{~m})$ or deeper $(10$ to $15 \mathrm{~m})$. The distribution of larvae in the cohort of 26 May is consistent with wind-driven circulation. The southerly winds on this day would be expected to drive surface waters onto the sand dollar bed and produce a deeper current leaving the sand dollar bed. In contrast, for the cohort of larvae found on 12 June almost all larvae were near the surface. At Site A, $99 \%$ of the larvae caught were in the shallower of the 1 and $10 \mathrm{~m}$ samples. At Site $\mathrm{A}^{\prime}$ where 3 depths were sampled, $85 \%$ were at $1 \mathrm{~m}, 14 \%$ at $6 \mathrm{~m}$, and $<1 \%$ at $12 \mathrm{~m}$ (Table 2).

Though vertical distribution varied in the earlier stages, advanced-stage larvae that were caught later in the season were concentrated near the surface. On 4 October 1982, 2 samples from a net towed horizontally at 2 depths at Site $C$ showed late-stage larvae with well-developed rudiments in the surface sample only. A more extensive series of pump samples on 22 August 1983 showed advanced-stage larvae with well-developed rudiments in surface water (Table 2). For this series, temperature and salinity data suggest little difference in the water characteristics sampled at the 2 depths for each site, and less advanced larvae were found in all salinities (Tables 2 \& 4). Surface water pumped $2 \mathrm{~d}$ earlier (20 August) at sites $\mathrm{A}^{\prime}, \mathrm{C}$. and SJC also contained advanced-stage larvae, though no deeper samples were taken this day (Table 2).

\section{Field evidence for delay of metamorphosis}

On dates in October 1982, and August 1983, many of the advanced stage larvae were partially metamorphosed when examined. This indicates that they were capable of metamorphosis and may have begun metamorphosis in the net before preservation. No completely metamorphosed individuals were seen that might indicate they had metamorphosed in the water column prior to collection.

The stage of larval development and length of arm rods was examined in larvae found in East Sound on 4 October 1982 and 22 August 1983 (Fig. 4). On both dates larvae of advanced developmental stage contain- 
Table 4. Temperature and salinity data for 2 depths at sites in East Sound on $22 \mathrm{Aug}$ 1983. Sites are shown in Fig. 1

\begin{tabular}{|c|c|c|c|c|c|c|}
\hline \multirow{2}{*}{$\begin{array}{l}\text { Depth of } \\
\text { sample }\end{array}$} & & \multicolumn{5}{|c|}{ Site (bottom depth) } \\
\hline & & $\begin{array}{c}\text { Over bed } \\
(1.5 \mathrm{~m})\end{array}$ & $\begin{array}{c}\mathrm{A} \\
(10 \mathrm{~m})\end{array}$ & $\begin{array}{c}B \\
(25 \mathrm{~m})\end{array}$ & $\begin{array}{c}C \\
(30 \mathrm{~m})\end{array}$ & $\begin{array}{c}E \\
(25 \mathrm{~m})\end{array}$ \\
\hline \multirow[t]{2}{*}{$1 \mathrm{~m}$} & Temp. $\left({ }^{\circ} \mathrm{C}\right)$ & 15 & 15 & 13.5 & 13 & - \\
\hline & Salinity $(\%)$ & 28 & 29 & 29 & 29 & 29 \\
\hline \multirow[t]{2}{*}{$10-15 \mathrm{~m}$} & Temp. $\left({ }^{\circ} \mathrm{C}\right)$ & - & 13.8 & 13 & 12.5 & 12 \\
\hline & Salinity $(\%)$ & - & 29 & 30 & 30 & 29 \\
\hline
\end{tabular}

ing a well-developed juvenile rudiment had shorter larval rod lengths than the earlier stage, 8-armed larvae. (For 4 October 1982, Mann-Whitney, $P=0.016$, $\mathbf{n}=15$ and 7 for early-and late-stage 8-armed larvae; for 22 August 1983, $\mathrm{P}=0.001, \mathrm{n}=7$ and 7.) Not all larvae of advanced-stage had shortened larval arms on 4 October 1982 (Fig. 4) and comparison between ad-

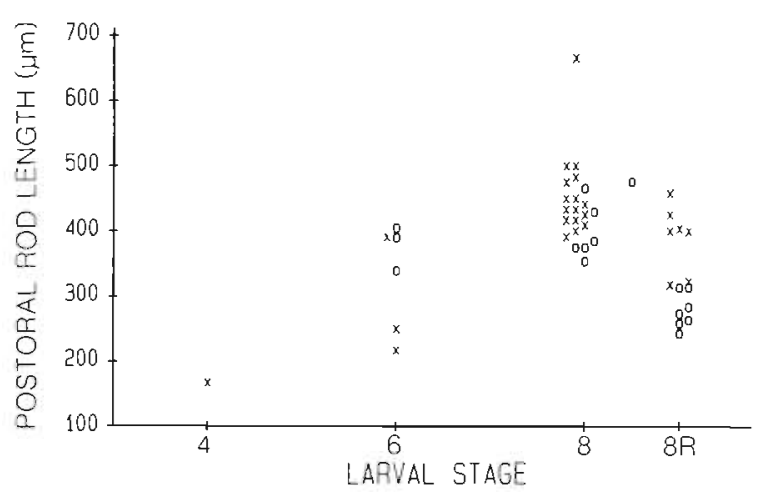

Fig. 4. Dendraster excentricus. Stage-specific larval rod lengths for the 2 dates that advanced stage larvae were found in East Sound. Abscissa: larval stage determined by numbers of larval arms; ordinate: length of postoral rod. Stage $8 \mathrm{R}$ is the most advanced and indicates larvae with a well-developed juvenile rudiment and juvenile spines. (x): 4 Oct 1982; (이: 22 Aug 1983

vanced stages on the 2 dates shows that larvae from 4 October 1982 had significantly longer arm rods than arm rods of larvae from 22 August 1983 (Mann-Whitney, $\mathrm{P}=0.001, \mathrm{n}=7$ and 7 ). Shortened larval arms in the most advanced stages may indicate delay of metamorphosis.

\section{DISCUSSION}

During the parts of 2 seasons that larval populations were sampled, no evidence was found that sand dollar larvae stayed near the adult population long enough to insure settling in their own local population. All the cohorts of larvae persisted near the adult population for 3 or $4 \mathrm{~d}$ prior to being sampled. Three of these cohorts dispersed during the 2 to $3 \mathrm{~d}$ after they were first found. Apparently, larvae from East Sound contribute to a regional larval pool that supplies the many isolated adult sand dollar populations in the Puget Sound region. In 1 sample interval (May 1982), due probably to the circumstances of wind-driven circulation and the fjord-like nature of the body of water, a small number of locally produced larvae probably did persist in the vicinity of the adult population for $2 \mathrm{wk}$ after they were released into the plankton. This amount of time represents approximately half the intermediate time for larval development of Dendraster excentricus in the laboratory (author's obs., Highsmith 1982, Paulay et al. 1985; I. Boidron-Metairon unpubl. obs.). In East Sound, larvae with behavior similar to those of $D$. excentricus and with pelagic periods of less than $2 \mathrm{wk}$ could be expected to settle in the same fjord.

There is no apparent mechanism for retention of sand dollar larvae in East Sound. In fact, Dendraster excentricus shows several characteristics that could increase the spread of sibling offspring (R. R. Strathmann 1974). The pelagic period of $3+w k$ indicates a potential for wide dispersal of siblings on the order of $300 \mathrm{~km}^{2}$ (Okubo 1971). The population spawns multiple times, and because all individuals have large gonads from May through August (author's obs.), individuals probably spawn multiple times. There was slight variation between years in the timing of spawning, though all 4 cohorts of early stage larvae of $D$. excentricus were produced during spring tides that caused low tide exposure of the adult populations. Spawning on spring tides might also maximize spread of larvae because of large tidal amplitude.

Except for the advanced larval stages of Dendraster excentricus, larvae of both echinoid species sampled in this study appeared to behave as passively dispersed particles. Pulses of larvae noted in 1982 were transported out of or into East Sound apparently by winddriven circulation. The drop in larval abundance of these pulses probably reflects dilution as well as larval mortality. It is, however, not possible to partition losses between these 2 factors, because wind-driven circulation is variable and of unknown magnitude. The passive movement of larvae within a water mass is consistent with the findings by Banse $(1955,1956$, in press) for 18 species of polychaetes and 6 species of echinoderms in Kiel Bay, Federal Republic of Germany. The lack of consistent pattern in stratification of early stage larvae in pumped samples in 1983 also suggests that their distribution was under the control of physical factors.

Advanced stage larvae of Dendraster excentricus were only found in the upper region of the water column. Thorson $(1946,1964)$ noted that many intertidal species have larval stages that are concentrated in 
surface waters or in the upper layers of waters in which they originate. An association with the upper region of the water column may enhance the opportunity of these larvae to encounter suitable habitat. Upper layers are moved the greatest amount by wind-driven circulation and are also the most likely to encounter intertidal areas. Grosberg (1982) found that vertical distributions of adults of 2 species of intertidal bamacles were matched by vertical distributions of cyprid larvae in adjacent waters. For East Sound a prevailing southerly wind would be expected to transport the advanced stage larvae into the intertidal adult habitat. $D$. excentricus occurs intertidally throughout Puget Sound and a mechanism of wind-driven surface transport of larvae to adult habitats would be expected to work there.

Whether the mechanism of surface transport of larvae to adult habitats applies to the species as a whole is uncertain. On the outer coast Dendraster excentricus occurs subtidally just outside the zone of wave breakage on many sandy beaches (Merrill \& Hobson 1970 , Morin et al. 1985). If advanced-stage sand dollar larvae on the open coast are distributed near the surface, the mechanism documented by Shanks (1983) in which larvae associated with surface slicks are transported shoreward could be important for these populations. However, encountering the benthic population would still require downward mixing of surface waters containing larvae such that larvae encounter adult populations. Cameron \& Rumrill (1982) found periodic occurrences of larvae of $D$. excentricus (including some mature larvae) over an adult sand dollar bed in Monterey Bay, but the spatial and temporal scale on which they sampled does not allow determination of the mechanism by which larvae moved into the area or reach the bottom.

How advanced-stage larvae become associated with surface water is not known. Decreased larval specific gravity and increased swimming rate in advancedstage larvae may concentrate these stages at the surface (Pennington \& Emlet in press). Alternatively, these advanced larvae in the upper layers may have bcen associated with a water mass distinct from deeper water. Samples of temperature and salinity from 22 August 1983 show 3 salinities and because advanced stages occur in 2 salinities and less advanced stages occur in all 3, larval distribution is not explained by distinct water masses.

Larvae develop in the plankton to the point where they are capable of metamorphosis, though they may or may not be near suitable substrate when they reach this state of development. Whether larvae actually delay metamorphosis, how long larvae can maintain their competence to metamorphose and what costs there might be to the developing juvenile are largely unknown. Highsmith \& Emlet (in press) found that delayed larvae of Dendraster excentricus showed a reduction of larval arm length during the $6 \mathrm{wk}$ that competent larvae were kept without metamorphosing and that one cost of delaying metamorphosis is slower juvenile growth. The range of larval rod lengths of the various stages of larvae found in East Sound in 4 October 1982 and 22 August 1983 (Fig. 4) may indicate that the advanced larvae had delayed metamorphosis for up to several weeks. Mean lengths of these rods for the advanced stages were significantly shorter than the next younger stage on both dates and the mean length for advanced stages on 22 August 1983 was significantly shorter than that on 4 October 1982. These results suggest that the time that advanced larvae delayed metamorphosis was longer for the 22 August 1983 sample.

There are few other data indicating delay of metamorphosis in field populations. Paine (1963) explained that different larval shell lengths that he found on adult shells in 2 separate populations of the inarticulate brachiopod Glottidia pyramidata could result from what he called 'inshore' and 'drift' larvae. The drift larvae apparently matured more slowly and reached a larger size prior to metamorphosis, but delayed metamorphosis with continued shell growth may have also produced the pattern noted in adult populations. Delay of metamorphosis may also explain different shell sizes noted for different larval populations of the bivalve Mytilus edulis (Bayne 1965, but see also Lutz \& Jablonski 1978). Hadfield (1978) argued that most of the tornaria larvae of the enteropneust Ptychodera flava, that he collected around Hawaii, were capable of metamorphosis and may have delayed metamorphosis for up to 4 or 5 mo

The combination of a well-defined local population of adults, a fjord-like body of water, and predominantly wind-driven circulation have allowed study of dispersal of early stage larvae from and retum of advanced larvae to a benthic population. Numerous studies have examined the mechanisms by which larvae, particularly the relatively large and fast swimming crustacean larvae, might be retained in estuaries or returned to adult habitat for settlement (e.g. Bousfield 1955, Lough 1976, Boicourt 1982, Sulkin \& van Heukelem 1982). Other studies suggest that the slower swimming, smaller, ciliated larvae behave as passive particles that move with a water mass and are distributed into a suitable habitat according to patterns of circulation and sedimentation (e.g. Thorson 1946, Banse 1955, 1956, Seliger et al. 1982, Hannan 1984, but see also Wood \& Hargis 1971). While many of the hypotheses put forward in these studies are plausible, conclusions for populations are restricted because of spatial scale, interactions of physical and biological 
processes, and unknown sources of larvae. The present study indicates that fjord-like bodies of water may provide an appropriate set of circumstances that will allow sampling of a known source of larvae so that questions of general interest in larval biology may be addressed with field populations.

Acknowledgements. I thank R. R. Strathmann for continuous encouragement during the field study. I am grateful to $R$. R. Strathmann, R. T. Paine, A. J. Kohn, K. Banse, J. T. Pennington, J. Christy, and P. Mace whose comments and criticism have improved the manuscript. Laboratory facilities and boats were provided by the Friday Harbor Laboratories, University of Washington. This research was supported by NSF grants OCE 8008310 and OCE 8400818 to R. R. Strathmann.

\section{LITERATURE CITED}

Banse, K. (1955). Über das Verhalten von meroplanktischen Larven aus der Kieler Bucht. Kieler Meeresforsch. (Sonderh.) 11: 188-200

Banse, K. (1956). Über den Transport von meroplanktischen Larven aus dem Kattegatt in die Kieler Bucht. Ber. dt. wiss. Kommn Meeresforsch. 14: 147-164

Banse, K. (in press). Vertical distribution and horizontal transport of planktonic larvae of echinoderms and benthic polychaetes in an open coastal sea. Bull. mar. Sci. 39

Bayne, B. L. (1965). Growth and delay of metamorphosis of the larvae of Mytilus edulis. Ophelia 2: 1-47

Birkeland, C., Chia, F. S. (1971). Recruitment risk, growth and age of sand dollars, Dendraster excentricus. J. exp. mar. Biol. Ecol. 6: 265-278

Boicourt, W. C. (1982). Estuarine larval retention mechanisms on two scales. In: Kennedy, V. S. (ed.) Estuarine comparisons. Academic Press, New York, p. 445-457

Bousfield, E. L. (1955). Ecological control of the occurrence of barnacles in the Miramichi estuary. Bull. natn. Mus. Can. Biol. Ser. 46, 137: 1-65

Bovard, J. F., Osterud, H. L. (1918). Partial list of the animals yielding embryological material at the Puget Sound Biological Station. Publs Puget Sound mar. biol. Stn 2: $127-137$

Burke, R. D. (1984). Pheromonal control of metamorphosis in the sand dollar, Dendraster excentricus. Science 225: $442-443$

Cameron, R. A., Rumrill, R. R. (1982). Larval abundance and recruitment of the sand dollar Dendraster excentricus in Monterey Bay, California, USA. Mar. Biol. 70: 197-202

Freeland, H. J., Farmer, D. M., Levings, C. D. (ed.) (1980). Fjord oceanography. NATO Conference 1979, Series IV, Vol. 4. Plenum, New York

Gage, J. (1972). A preliminary study of the benthic macrofauna and sediments in Lochs Etive and Creran, sealochs along the west coast of Scotland. J. mar. biol. Ass. U.K. 52: 237-246

Gaines, S., Roughgarden, J. (1985). Larval settlement rate: a leading determinant of structure in an ecological community of the marine intertidal zone. Proc. natn. Acad. Sci. U.S.A. 82 : $3707-3711$

Grosberg, R. K. (1982). Intertidal zonation of barnacles: the influence of planktonic zonation of larvae on vertical distribution of adults. Ecology 63: 894-899

Hadfield, M. G. (1978). Growth and metamorphosis of plank- tonic larvae of Ptychodera flava (Hemichordata: Enteropneusta). In: Chia, F. S., Rice, M. E. (ed.) Settlement and metamorphosis of marine invertebrate larvae. Elsevier, New York, p. 247-254

Hannan, C. A. (1984). Planktonic larvae may act like passive particles in turbulent near-bottom flows. Limnol. Oceanogr 29: 1108-1116

Highsmith, R. C. (1982). Induced settlement and metamorphosis of sand dollar (Dendraster excentricus) larvae in predator free sites: adult sand dollar beds. Ecology 63: 329-337

Highsmith, R. C., Emlet, R. B. (in press). Delayed metamorphosis: effect on growth and survival of juvenile sand dollars (Echinoidea, Clypeasteroida). Bull. mar. Sci. 39

Keough, M. J., Downes, B. J. (1982). Recruitment of marine invertebrates: the role of active larval choices and early mortality. Oecologia (Berl.) 54: 348-352

King, K. (1976). East Sound cruise report. Friday Harbor Laboratories Class Paper, Univ. of Washington

Lough, R. G. (1976). Larval dynamics of the Dungeness crab, Cancer magister, off the central Oregon coast, 1970-71. Fish. Bull. U.S. 74: 353-375

Lutz, R. A., Jablonski, D. (1978). Larval bivalve shell morphometry: A new paleoclimatic tool? Science 202: 51-53

McEdward, L. R. (1984). Morphometric and metabolic analysis of the growth and form of an echinopluteus. J. exp. mar. Biol. Ecol. 82: 259-287

Merrill, R. J., Hobson, E. S. (1970). Field observations of Dendraster excentricus, a sand dollar of western North America. Am. Midl. Nat. 83: 595-624

Morin, J. G., Kastendiek, J. E., Harrington, A., Davis, N. (1985). Organization and patterns of interactions in a subtidal sand community on an exposed coast. Mar. Ecol. Prog. Ser. 27: 163-185

Mortensen, T. (1921). Studies of the development and larval forms of echinoderms. G.E.C. Gad., Copenhagen

Niesen, T. M. (1977). Reproductive cycles in two populations of the Pacific sand dollar, Dendraster excentricus. Mar. Biol. 42: 365-373

Okubo, A. (1971). Oceanic diffusion diagrams. Deep Sea Res. 18: 789-802

Paine, R. T. (1963). Ecology of the brachiopod Glottidia pyramidata. Ecol. Monogr. 33: 255-280

Paulay, G., Boring, L., Strathmann, R. R. (1985). Food limited growth and development of larvae: experiments with natural seawater. J. exp. mar. Biol. Ecol. 93: 1-10

Pearson, T. H. (1970). The benthic ecology of Loch Linnhe and Loch Eil, a sea loch system on the west coast of Scotland. I. The physical environment and distribution of the macrobenthic fauna. J. exp. mar. Biol. Ecol. 5: 1-34

Pearson, T. H. (1980). Macrobenthos of fjords. In: Freeland, H. J., Farmer, D. M., Levings, C. D. (ed.) Fjord oceanography. NATO Conference, 1979 Series IV, Vol. 4. Plenum, New York, p. 569-602

Pennington, J. T., Emlet, R. B. (in press). Ontogenetic and diel vertical migration of a planktonic larva, Dendraster excentricus (Eschscholtz): occurrence, causes, and probable consequences. J. exp. mar. Biol. Ecol.

Rasmussen, E. (1973). Systematics and ecology of the Isefjord marine fauna (Denmark). Ophelia 11: 1-507

Rattray, M., Jr. (1967). Some aspects of the dynamics of circulation in fjords. In: Lauff, G. H. (ed.) Estuaries. AAAS, Washington, D.C., p. 52-62

Seliger, H. H., Boggs, J. A., Rivkin, R. B., Biggley, W. H., Aspden, K. R. H. (1982). The transport of oyster larvae in an estuary, Mar. Biol. 71: 57-72

Shanks, A. L. (1983). Surface slicks associated with tidally 
forced internal waves may transport pelagic larvae of benthic invertebrates and fishes shoreward. Mar. Ecol. Prog. Ser. 13: 311-315

Sokal, R. R., Rohlf, F. J. (1981). Biometry, 2nd edn. Freeman, San Francisco

Strathmann, M. (1974). Methods in developmental biology, echinodermata, echinoidea. Friday Harbor Laboratories, University of Washington

Strathmann, R. R. (1971). The feeding behavior of planktotrophic echinoderm larvae: mechanisms, regulation, and rates of suspension-feeding. J. exp. mar. Biol. Ecol. 6: $109-160$

Strathmann, R. R. (1974). The spread of sibling larvae of sedentary marine invertebrates. Am. Nat. 108: 29-44

Strathmann, R. R. (1978). Length of pelagic period in echinoderms with feeding larvae from the Northeast Pacific. J. exp. mar. Biol. Ecol. 34: 23-27

Strathmann, R. R. (1979). Echinoid larvae from the northeast Pacific (with a key and comment on an unusual type of planktotrophic development). Can. J. Zool. 57: 610-616

Sulkin, S. D., van Heukelem, W. (1982). Larval recruitment in the crab Callinectes sapidus Rathbun: an amendment to the concept of larval retention in estuaries. In: Kennedy V. S. (ed.) Estuarine comparisons. Academic Press, New York, p. 459-475

Thorson, G. (1946). Reproduction and larval development of Danish marine bottom invertebrates with special reference to the planktonic larvae in the Sound (Oresund) Meddr Kommn Danm. Fisk. -og Havunders., Ser. Plankton 4: $1-523$

Thorson, G. (1964). Light as an ecological factor in the dispersal and settlement of larval of marine bottom invertebrates. Ophelia 1: 167-208

Underwood, A., Denley, E. (1984). Paradigms, explanations and generalizations in models for the structure of intertidal communities on rocky shores. In: Strong, D. R., Simberloff, D., Abele, L. G., Thistle, A. B. (ed.) Ecological communities: conceptual issues and the evidence. Princeton Univ. Press, Princeton, New Jersey, p. 151-180

Wood, L., Hargis, W. J. (1971). Transport of bivalve larvae in a tidal estuary. In: Crisp, D. J. (ed.) Fourth European Marine Biological Symposium. Cambridge, England, p. 29-44

This article was presented by Dr. R. S. Scheltema; it was accepted for printing on April 28, 1986 